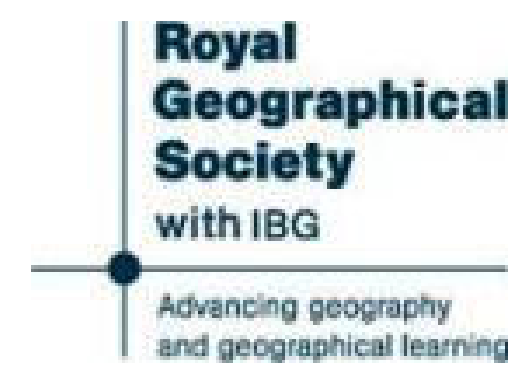

Modern Deep-Sea Research in the East Indian Archipelago

Author(s): G. A. F. Molengraaff

Source: The Geographical Journal, Vol. 57, No. 2 (Feb., 1921), pp. 95-118

Published by: The Royal Geographical Society (with the Institute of British Geographers)

Stable URL: http://www.jstor.org/stable/1781559

Accessed: 26/12/2014 09:22

Your use of the JSTOR archive indicates your acceptance of the Terms \& Conditions of Use, available at

http://www.jstor.org/page/info/about/policies/terms.jsp

JSTOR is a not-for-profit service that helps scholars, researchers, and students discover, use, and build upon a wide range of content in a trusted digital archive. We use information technology and tools to increase productivity and facilitate new forms of scholarship. For more information about JSTOR, please contact support@jstor.org. 
What will happen there none of us can say. Whether the Persians will accept our agreement or not none of us know. I cannot help thinking that if we do come to a Mohammedan federation in Central Asia it would conduce to stability in those regions, but none of us can say what will happen there. We can only hope that the Afghans will see wisdom, and that they will turn to the British instead of to the Bolshevists, and that we shall not have any fresh trouble with them as we had last year, when they so outrageously and wantonly attempted to invade India.

The PResident : I am sure we should wish to congratulate Major Bailey upon his wonderful escapes and the great resource which he showed in dealing with critical situations. He is the most remarkable man I know of for getting himself into nasty situations and getting himself out of them again.

\section{MODERN DEEP-SEA RESEARCH IN THE EAST INDIAN ARCHIPELAGO}

\section{Prof. G. A. F. Molengraaff, of Delft}

Read at the Meeting of the Society, 7 Fune r920. Map following $p$. I52.

CUBMARINE topography all over the world is much simpler than the $D$ topography of the subaerial portion of the globe. This is, at least near the continental borders, evidently the consequence of the covering or blanketing influence of continuous sedimentation on the relief of the sea-bottoms contrasting with the carving and sculpturing influence of never-ceasing erosion on the land surfaces. Wherever this rule does not hold good the submarine topography, not yet being obliterated by sedimentation, must be of recent date. A bold relief of the sea-bottom is therefore, at least near the continents, apt to indicate portions of the Earth's crust which either have been warped in recent geological time or still continue to be orogenetically active, and thus continually rejuvenate and remould the sculpture of their surface. In this paper the latter alternative will be discussed for the Australasian seas.

One of the major results of deep-sea research, a branch of science of modern date, has been the statement of the fact that the so-called mediterranean seas are, as compared with the grand oceans, characterized by a bold and diversely developed submarine topography.

Mediterranean seas are, as the name indicates, seas which separate continents one from the other; in a somewhat narrower sense the name is given to those mediterranean seas which separate the great continents of the northern hemisphere from the southern continents, viz. the Caribbean Mediterranean between North and South America, the Mediterranean Sea in the strict sense between Europe and Africa, and the Australasian Mediterranean sea between Asia and Australia.

One of the peculiarities of the topography of the mediterranean seas proved to be the existence of basins, often of great extent, separated from 
the great oceans by submarine barriers or ridges of varying depths. To these basins, notwithstanding their great depths, the cold water from the abysmal portion of the oceans cannot have access. Consequently in each of those basins the temperature of the water below the deepest point of the ridge or barrier separating it from the ocean remains constant, whatever figure its entire depth may attain.

The submarine topography of the European Mediterranean Sea is known by various investigations dating from the year 1879 , and our knowledge of the Caribbean Mediterranean Sea is chiefly based upon the results obtained by the Blake in the years $1877-1880$. In the Australasian Mediterranean Sea the first deep soundings have been made with an inadequate equipment by Siedenburg in the year I858. A small but important series of deep soundings carried out by the famous Challenger Expedition in the years 1874 and 1875 made known the great depths of some of the basins of the East Indian archipelago ; and later a few data were added to the list by the soundings of the German vessels Gazelle in the year 1875 and Valdivia in the year 1899 , as well as by those of the British vessels Egeria and Rambler in the years 1888 and 1890 .

Only in the years 1899 and r 900 a well-equipped expedition, the Siboga Expedition, directed by Prof. M. Weber, succeeded in revealing many of the secrets hidden by the East Indian waters. By 238 soundings, made at the same number of stations, so many data were obtained about the submarine topography, that upon these and some other records mentioned above, the present Vice-Admiral G. F. Tydeman (Bibl. 22), then the naval chief of the Siboga Expedition, found it possible to publish in the year 1903 the first chart of the depths of the sea in the East Indian archipelago.

Additional data were obtained by later deep-sea work carried out by the Dutch vessels Bali, Edi, and Telegraaf in the years 1903,1905 and I910, the German vessel Planet in the year 1906, and others. Every new fact added to our knowledge of the submarine topography of the East Indian archipelago has given fresh evidence of its diversity, and proves its features to be bolder and more complicated the more they are known. At present no less than thirty larger and smaller deep-sea basins are known to exist in the East Indian archipelago. They are enumerated in the list given on p. 97, with the exception of some minor depressions of small extent. In this list are also incorporated the Andaman basin and the South China basin, although they only touch the borders of the archipelago, and do not belong to it.

To the deeper portions of the Andaman basin, the Mentawei basin, the Java trough and the Timor basin, only the water of the Indian Ocean has access, whereas the deeper water of all the other basins is connected only with the Pacific Ocean. The extensive basin of the Banda sea, and with it the Wetter trough, the Savu basin, the Flores basin, the Saleyer trough, and the Buton trough, is separated from both oceans by a rim, 
Basins of the East Indian ARchipelago.

\begin{tabular}{|c|c|c|c|c|c|c|c|}
\hline & & & & $\begin{array}{l}\text { Greatest } \\
\text { depth in } \\
\text { metres. }\end{array}$ & Authorities. & $\begin{array}{l}\text { Lowest point of } \\
\text { the rim separat- } \\
\text { ing the basin } \\
\text { from the } \\
\text { oceans. }\end{array}$ & $\begin{array}{l}\text { Temperature } \\
\text { of homotherm } \\
\text { water-mass } \\
\text { in degrees } \\
\text { Centigrade. }\end{array}$ \\
\hline Andaman basin & ... & $\cdots$ &.. & 4177 & Investigator? & I 200 & $5^{\cdot 2}$ \\
\hline Mentawei basin & $\ldots$ & $\ldots$ & .. & 1671 & Valdivia & 900 & $5^{\circ} 9$ \\
\hline Mentawei trough & or $\mathrm{St}$ & nda troug & & 5214 & Valdivia & - & - \\
\hline Java trough & $\ldots$ & .. $\quad .$. & .. & 7100 & Planet & 5800 & - \\
\hline Timor Sea ... & $\ldots$ & $\ldots$ & .. & 3109 & - & \pm 2000 & $3^{\circ} \circ$ \\
\hline Kei trough ... & $\ldots$ & $\ldots$ & .. & 3565 & Siboga & \pm 1600 & - \\
\hline Ceram-Aru troug & & $\ldots$ & .. & 2571 & Rambler & \pm 1600 & - \\
\hline Flores Sea ... & ... & $\ldots$ & ... & 5121 & Egeria & 1650 & $3 \cdot 3$ \\
\hline Savu Sea ... & $\ldots$ & $\ldots$ & .. & $375^{8}$ & Gazelle & 1650 & $3 \cdot 3$ \\
\hline Wetter trough & $\ldots$ & $\ldots$ & .. & 3257 & - & 1650 & $3 \cdot 3$ \\
\hline Saleyer trough & $\ldots$ & $\ldots$ & .. & 3110 & Siboga & 1650 & $3 \cdot 3$ \\
\hline Buton trough & $\cdots$ & $\cdots$ & .. & 3335 & Bali & 1650 & $3 \cdot 3$ \\
\hline Kalao trough & $\ldots$ & $\ldots$ & ... & 2124 & - & - & - \\
\hline North-western Ba & anda $S$ & & .. & 5098. & Bali & 1650 & $3 \cdot 3$ \\
\hline Central Banda Se & & ... $\quad$. & .. & 5121 & Challenger & 1650 & $3 \cdot 3$ \\
\hline $\begin{array}{c}\text { Eastern Banda S } \\
\text { Weber deep }\end{array}$ & ea, in & luding th & & 6505 & Penguin & 1650 & $3 \cdot 3$ \\
\hline Batyan trough & ... & $\ldots$ & .. & 4709 & - & \pm 2000 & - \\
\hline Gorontalo trough & $\ldots$ & $\ldots$ & .. & 3755 & Bali & $\pm \mathrm{I} 880$ & $3^{\cdot} \mathrm{I}$ \\
\hline Sangir trough & $\ldots$ & $\ldots$ & .. & 3302 & Siboga & $\pm \mathrm{I} 880$ & - \\
\hline Togean basin & $\ldots$ & .. & .. & 1800 & Bali & - & - \\
\hline Tomini basin & $\ldots$ & $\ldots$ & ... & 2006 & , & - & - \\
\hline $\begin{array}{c}\text { Celebes Sea, inc } \\
\text { of Makassar }\end{array}$ & luding & the strai & & 5 I I I & Rambler & 1400 & $3 \cdot 7$ \\
\hline Sulu basin ... & $\ldots$ & $\ldots$ & .. & 4663 & Challenger & 380 & $10 \cdot 2$ \\
\hline Halmaheira basin & $\ldots$ & $\ldots \quad$. & .. & 2039 & Siboga & \pm 1100 & $\div$ \\
\hline Mindanao trough, & , centr & al portion & & 8500 & Planet & - & - \\
\hline Mindanao trough, & , south & rn portior & & 7243 & Edi & - & - \\
\hline China Sea, centra & al port & & ... & 4965 & Egeria & 一 & $2 \cdot 8$ \\
\hline Palawan trough & $\ldots$ & $\ldots$ & ... & 2877 & - & - & - \\
\hline
\end{tabular}

the lowest point of which is situated at a depth of 1600 metres between the Sulu islands and Obi Major. Over this rim the water of the Pacific Ocean communicates through the Molucca passage with the deeper water of the Banda basin. The homothermic water below 1650 metres in the Banda sea, and all the basins connected with it have a uniform temperature of $3.3^{\circ} \mathrm{C}$. The Sulu basin is more enclosed than any of the others, and below 380 metres its water has no communication at all with the oceans. From that depth to the bottom at $466_{3}$ metres its water has a temperature of $10 \cdot 2^{\circ} \mathrm{C}$. throughout.

The deposits formed in those more or less enclosed basins have been examined by Böggild (Bibl. 2). As none of them are formed very far from land, terrigenous deposits much preponderate, and pure oceanic deposits free from terrigenous elements are absent. Nevertheless Böggild adopts the classification introduced by Murray and Renard for the oceanic deposits collected by the Challenger Expedition, remarking, however, that all the oozes found in those basins are more or less modified by an 
admixture of terrigenous material. Thus, for instance, both blue mud and volcanic mud are called Globigerina ooze by Böggild as soon as they contain more than fifty per cent. of carbonate of lime in the form of shells of Globigerina.

The most remarkable outcome of the researches of Böggild is, that in the basins of the East Indian archipelago the percentage of carbonate of lime in the bottom deposits diminishes with increasing depths at a rate more rapid than in the oceans. The decrease in the percentage of the carbonate of lime in the deposits of those basins towards the depths is shown in the following table:

\begin{tabular}{|c|c|c|c|c|c|c|c|c|c|}
\hline \multirow{2}{*}{$\begin{array}{r}\text { Depth in metres. } \\
0-500 \quad . .\end{array}$} & \multirow[b]{2}{*}{$\cdots$} & \multirow[b]{2}{*}{$\ldots$} & \multicolumn{4}{|c|}{$\begin{array}{l}\text { Number of } \\
\text { samples. }\end{array}$} & \multicolumn{3}{|c|}{$\begin{array}{l}\text { Average percentage } \\
\text { of carbonate of lime }\end{array}$} \\
\hline & & & $\ldots$ & $\ldots$ & 26 & $\ldots$ & $\ldots$ & $\ldots$ & $43 \cdot 2$ \\
\hline $500-1000 \ldots$ & $\ldots$ & $\ldots$ & $\ldots$ & $\ldots$ & I6 & $\ldots$ & $\ldots$ & $\ldots$ & $38 \cdot 0$ \\
\hline $1000-1500 \ldots$ & $\ldots$ & $\ldots$ & $\ldots$ & $\ldots$ & 12 & $\ldots$ & $\ldots$ & $\ldots$ & $3^{1} \cdot 2$ \\
\hline $1500-2000 \ldots$ & $\ldots$ & $\ldots$ & $\ldots$ & $\ldots$ & 10 & $\ldots$ & $\ldots$ & $\ldots$ & $3^{2} \cdot 2$ \\
\hline $2000-2500 \ldots$ & $\ldots$ & $\ldots$ & $\ldots$ & $\ldots$ & II & $\ldots$ & $\ldots$ & $\ldots$ & $24^{\circ} \mathrm{O}$ \\
\hline $2500-3000 \ldots$ & $\ldots$ & ... & $\ldots$ & $\ldots$ & 9 & $\ldots$ & $\ldots$ & $\ldots$ & 25.7 \\
\hline $3000-3500 \ldots$ & ... & $\ldots$ & $\ldots$ & $\ldots$ & 4 & $\ldots$ & $\ldots$ & $\ldots$ & $23^{\circ} 6$ \\
\hline $3500-4000 \ldots$ & $\ldots$ & $\ldots$ & $\ldots$ & $\ldots$ & 4 & $\ldots$ & $\ldots$ & $\ldots$ & 8.4 \\
\hline$>4000 \ldots$ & $\ldots$ & $\ldots$ & $\ldots$ & $\ldots$ & 14 & $\ldots$ & $\ldots$ & $\ldots$ & $2 \cdot I$ \\
\hline
\end{tabular}

In the open oceans Murray and Renard (Bibl. I5, p. 279) have found the relations between the depth of the sea and the percentage of carbonate of lime in the deposits to be as follow :

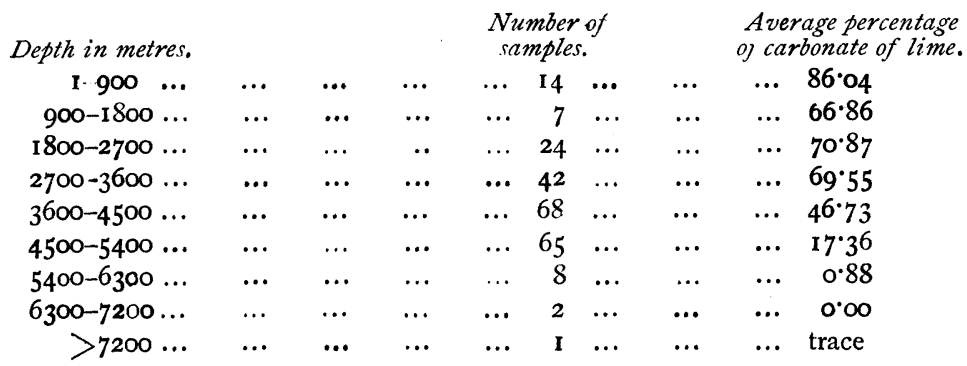

These two tables are not directly comparable on account of the strong terrigenous character of the deposits of the basins of the East Indian archipelago. Nevertheless they show clearly how in the basins from a depth of 3500 metres downwards the percentage of carbonate of lime rapidly decreases and soon becomes smaller than in the oceans. Whereas below 4000 metres in the basins the majority of the samples are completely limeless, and the average percentage from all the samples is as low as $2 \cdot 1$, in the open oceans between 4500 and 5400 metres the percentage of carbonate of lime in the deposits averages 17.36 , and the practically limeless zone only commences at a depth of about 5500 metres.

Böggild-although "with strong hesitation"-applies the name "red clay" to the limeless deposits found in the deepest portion of the Celebes basin and the Banda basin, although these deposits, the carbonate of 
lime being dissolved, are practically no more distinguishable from either blue mud or volcanic mud. This name is apt to cause confusion, because the red'clay of the oceans has a well-marked geological character of its own, having far more than any other deposit accumulated with extreme slowness. Böggild's red clay of the enclosed basins lacks this and any other geological character of its own.

This disappearance of the carbonate of lime in the deeper portions of the more or less enclosed basins is an unexpected result. The current opinion is that the progressive solution of carbonate of lime in the oceans with increasing depths must be attributed to the influence of the cold water of the polar regions, which by the hydrospheric circulation slowly but continuously replaces and refreshes the deepest sheets of water at the bottom of the oceans. This water contains a large percentage of oxygen in solution, and thus maintains the power of the deeper portions of the oceans to oxidize organic matter. The carbonic acid freed by this process of oxidization would give the same deep water the power to dissolve carbonate of lime, and thus to destroy those descending shells and skeletons of dead pelagic organisms which are composed of carbonate of lime.

Now, in the Banda basin and the Celebes basin, which are separated from the Molucca passage and thus from the Pacific Ocean by ridges of no greater depth than $165^{\circ}$ and 1400 metres respectively, the deeper water of the oceans which is richest in oxygen and carbonic acid has no access. Thus, according to generally accepted views the percentage of lime even in the deepest portions of these basins could not be less, or at least not much less, than in the Pacific Ocean in depths corresponding with the lowest point of the separating ridges.

Consequently, one would expect to find in the deposits in the deeper homothermic portions of these basins a rather large percentage of carbonate of lime, 50 per cent. or more. Böggild's analyses have shown that this is not the case. Böggild looks for local explanations, and suggests the possibility of the occurrence of submarine volcanoes as sources of carbonic acid, but this suggestion is not sustained by facts.

A similar case has been recorded from a portion of the Caribbean Mediterranean Sea, which huge basin from a depth of 1200 metres downward is separated from the Atlantic Ocean. Here in the Curaçao deep* at depths of about 5000 metres limeless deposits (red clay) are said to occur, whereas in another still deeper portion of the same basin, viz. in the Bartlett deep, the presence of pure Globigerina ooze is indicated. Our information about the deposits in the Caribbean Sea, however, is scanty as yet, and I have not succeeded in finding a discussion of the quoted occurrence of red clay in the Curaçao deep. The entire

* J. Murray and E. Philippi (Bibl. 16, Map i.); J. Murray and J. Hjort (Bibl. I7, Map iv.). A. Agassiz maps the bottom deposit in the Curaçao deep as a modified pteropode ooze (Bibl. x, vol. I, Fig. 19r). 
question of the occurrence of limeless deposits in enclosed deep-sea basins appears to be as yet open to explanation. According to what has been said above, one must expect these deep sea-basins, and in general the complicated submarine topography, of which they form the most conspicuous features, to be of modern origin. Before discussing their mode of origin it will, however, be found useful also to take into consideration what characteristics modern hydrographical research has disclosed in those other positions of the archipelago, where deep-sea basins do not occur. Here an entirely different aspect prevails.

Two great shelves attached to the continents of Asia and Australia extend far into the archipelago, as has been stated by Early (Bibl. 8, p. 395) in this Fournal as early as $\mathbf{1 8 4 5}$. They are known as the Asiatic bank or Sunda shelf, and the Australian bank or Sahul shelf. The Sunda shelf is the greatest shelf known on earth, measuring $\mathrm{I}, 850,000$ square kilometres. The surfaces of both the Sunda shelf and the Sahul shelf are characterized by their almost perfect evenness. The depth of the water on these banks averages about 30 fathoms (W. Earle, Bibl. 8, p. 359). On the Sunda shelf depths exceeding $3 \circ$ fathoms are extremely rare, and practically are only found in the south-eastern portion, where in the direction of the Makassar strait the depth increases rapidly; and again in the north, where towards the South China Sea the depth increases very slowly. A constant depth and a perfectly even and undisturbed surface of their bottoms are the outstanding features of these shelf seas. Thus the East Indian Archipelago proves to consist of two strongly contrasting portions (R. D. M. Verbeek, 24, p. 797), one with an exceptionally uniform and undisturbed submarine topography, and another with an extremely complicated structure.

Great as is the contrast between those two areas with regard to their present physical features, no less is this the case with regard to their geological history, as I have shown elsewhere (Bibl. II, p. 232). The area to which the shelf seas belong, at least since the close of the Pliocene Age, has been stable, and thus has not been disturbed by any orogenetic movements, whereas the area to which the deep-sea basins belong since that time has continued to be unstable and orogenetically very active.

The Shelf Seas and the former Sunda Land.-The almost perfect uniformity in depth of those shelf seas suggests that they are originated by changes of the sea-level rather than by diastrophism. In the year r9r 6 (Bibl. 13, p. 612) while discussing Daly's glacial-control theory (Bibl. 7) and again in the year 1919 (Bibl. 14, p. 404) the author has given his ideas on the causal relation between the origin of those shelf seas and the Pleistocene glaciation, which will be referred to shortly here, as far as the Sunda shelf is concerned. At the end of the Pliocene period or at the beginning of the Pleistocene Age the present Sunda sea probably consisted of low land or a group of islands. One might imagine an imperfect 
peneplain partly covered by the sea. At the beginning of the Ice Age the sea-level sank in consequence of the growth of the Pleistocene icecaps (see Penck, Bibl. I9 and 20; Daly, Bibl. 6 and 7) and stood at least 40 fathoms lower than at the present day. A great area was laid dry and united the present islands of Sumatra, Borneo, and Java. This land is called the Sunda land. This Sunda land probably has existed as a stable continental landmass at least since the beginning of the Neogene Age.

During the Pleistocene Age a period of long-continued erosion followed. This process was active, the erosive power of all the streams and rivers having been intensified by the lowering of their base-level. Then an extensive gradation-plane was formed, from which only here and there exceptionally resisting portions protruded as groups of rounded hills or monadnocks. The broad peneplain was bordered to the west, southwest, and south by the partly volcanic, partly non-volcanic high mountains of Sumatra and Java ; towards the north, north-east, and east by the huge granite bosses, the high sandstone plateaus, and the older mountain chains of Borneo. In this peneplain the rivers which flowed from the mountains united into two or more powerful streams, which discharged probably into the South China Sea and into the southern shallower portion of the strait of Makassar.

At the end of the glacial period the sea-level rose again to its present height consequent on the melting of the ice-caps. The Sunda peneplain was gradually submerged and for its greater part converted into a shelf sea, the great Sunda-shelf sea. The monadnocks, few in number, were isolated by the rising sea and now form groups of rocks and islands, emerging from the shelf sea, as for example Bangka, Billiton, Singkep, the islands of the Riow archipelago, the Karimata islands, the Karimon Java islands, and others.

This is of course a much simplified conception of what has happened in reality. The Ice Age has not been one single cold period, but a succession of colder glacial periods alternating with milder interglacial periods. Consequently the ice-caps more than once have grown to a large extent and have melted again. Thus we may surmise that during the first glacial period the Sunda peneplain, which probably already pre-existed in an imperfect state, has recommenced to develop; that it has been covered by the sea during the first interglacial period; that during the second glacial time it was rendered more perfect; that it was flooded again during the second interglacial time, and so on, until the last glacial period saw the peneplain in such a state of perfection, as is now illustrated by the floor of the Sunda-shelf sea.

If this theory holds good one must expect to find evidences of recent subsidence all along the coast of the Sunda sea. This is indeed the case. First of all, the land up to a great distance from the coast is flat and no traces of upheaved modern coastal formations of any importance are 
known. The even surface of the shelf is prolonged without altering its character far into the interior in the low peneplainized country surrounding the major portion of the Sunda sea. Along the western coast of Borneo a retreat of the sea to a depth of Io fathoms would connect no less than eighty smaller and larger islands * with the main land, and their higher portions with their smooth contours would be incorporated into the still

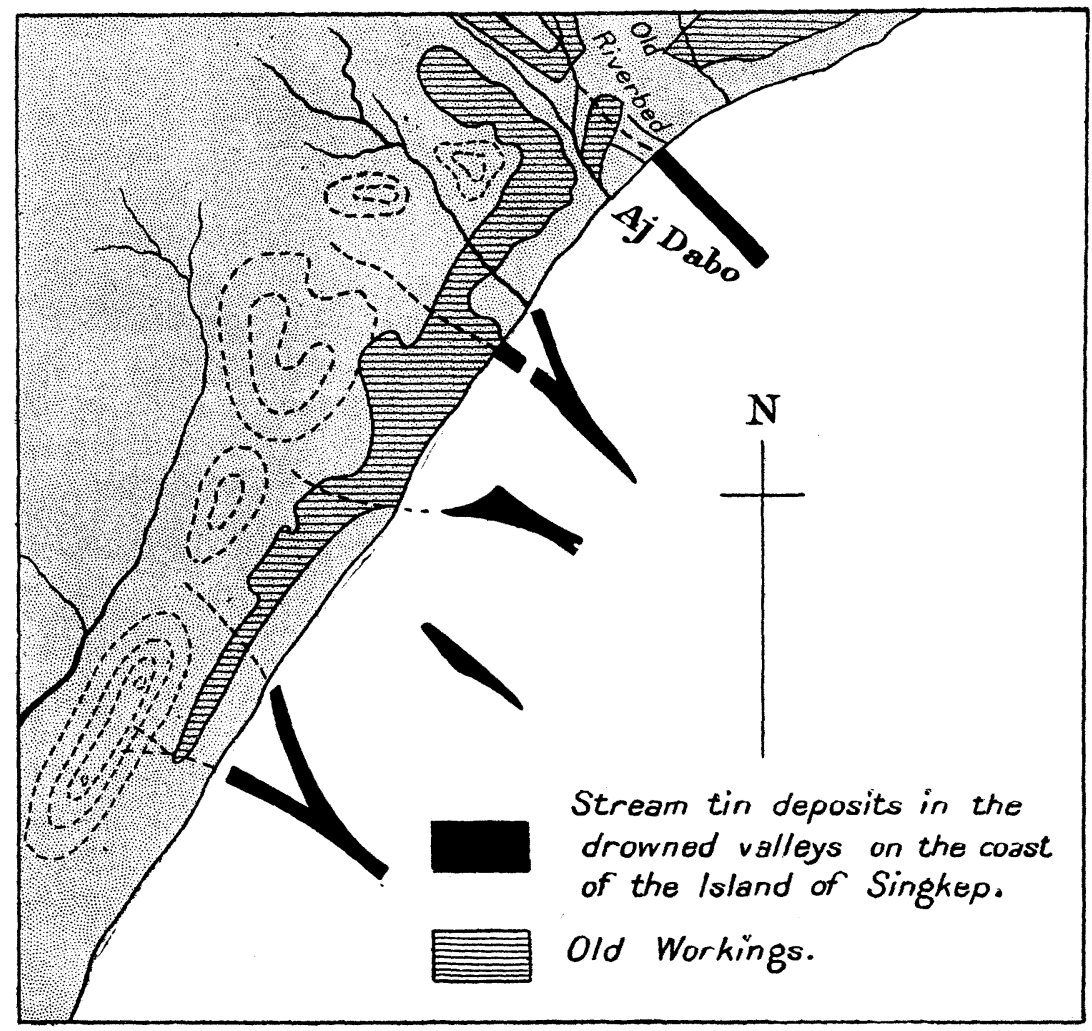

MILES

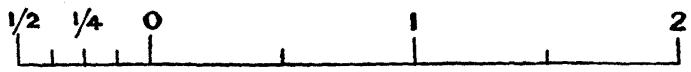

Fig. 1.-Stream tin in drowned valleys oft island of Singkep, Sunda Sea, east coast of Sumatra, south of Singapore

unflooded portion of the extensive peneplain of West Borneo without the scenery of the landscape being altered in any perceptible degree.

Further, deltas are generally wanting, although the rivers both of Borneo and Sumatra transport heavy loads of sediment towards the sea ; only two of them, the Pawan and the Kapuas, have built out a delta which, however, even in the case of the Kapuas, which carries more sediment than any of the other rivers, hardly pratrudes from the coast-line into the

* Not including low alluvial islands, exclusively composed of modern detritus. 
sea. In general the coast-lines are embayed, and the rivers possess wide funnel-shaped mouths with great depths in their lower courses. The submarine continuations of these rivers, i.e. their drowned portions, can

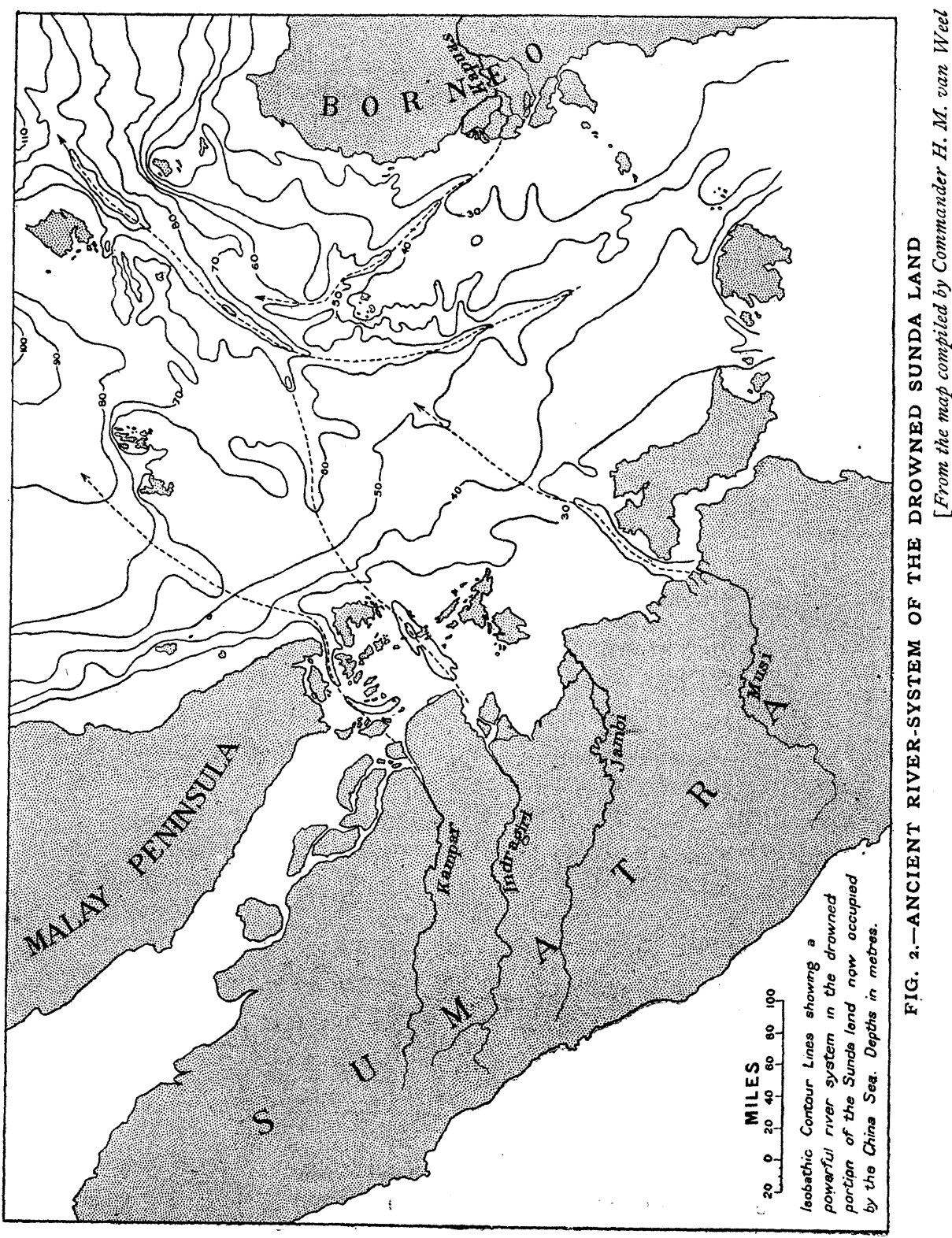

be traced in many instances. Thus the submarine course of the Sampit river can be traced to a distance of 35 kilometres from the coast as a shallow gully in the shelf. On the island of Singkep the tin ore deposited 
in the lowermost strata of the alluvium in the river-beds has been followed as far as 1300 metres out from the coast, lying at a depth of $9 \frac{1}{2}$ fathoms (I7 metres) below sea-level. The exploitation of this so-called sea-tin on the south-eastern coast of this island has revealed the existence of several drowned river-beds in the shelf sea (Fig. I).

Indeed, portions of some of the former powerful river systems formerly draining the now partially drowned Sunda land by the aid of the isobathic curves of the present Sunda-shelf sea can be reconstructed with a tolerable degree of accuracy. In Pleistocene time a main divide stretching across the Sunda sea from Sumatra over the islands of Bangka, Billiton, and the Karimata group towards Borneo probably separated the watersheds of at least two main streams, one draining the northern portion of the Sunda land and discharging into the South China Sea, the other draining the southern portion and discharging into the southernmost section of the strait of Makassar.

The northern main stream of the Pleistocene Sunda land is as a gully in the shelf beautifully shown on a bathymetric map of the South China Sea (Fig. 2), recently compiled by the commander of the Brak, H. M. van Weel.

The various rivers of Sumatra and Borneo discharging now into the Sunda-shelf sea are the dismembered side branches of these large main streams. Thus the Musi, one of the largest rivers of Sumatra, and the Kapuas, the largest river of West Borneo, both were confluents of the northern main stream, and consequently belonged to the same river system.

This hypothesis, according to Weber (Bibl. I4, p. 428), affords explanation of some remarkable facts in the geographical distribution of the freshwater fishes of Australasia. The fish fauna of the Musi and other big rivers of the east coast of Sumatra has a striking similarity to that of the Kapuas on the island of Borneo, although both river systems are now separated by a wide expanse of sea-water. On the contrary, the fish faunæ of the Kapuas of the west coast of Borneo and the Mahakkam or Kutei of the east coast of Borneo show great differences, notwithstanding the fact that both these rivers spring from the same divide. From a total of $\mathbf{I 4 2}_{2}$ species known, only 52 are common to both these rivers, the majority of these being found also in other parts of the Sunda islands. From the remaining 90 species 23 are found in the Mahakkam and 67 in the Kapuas. No less than 52 or 75 per cent. out of the latter 67 species are known to occur in the rivers of east Sumatra as well, whereas only I 2 species are restricted to the Kapuas. No less than 17 or 74 per cent. out of the 23 species which occur in the Mahakkam, but do not live in the Kapuas, are restricted to the Mahakkam and some neighbouring rivers. Three species out of these 23 only are known to occur in the Mahakkam as well as in the rivers of East Sumatra. Thus the Kapuas owes its superiority in number of its fish fauna as compared with that of the Mahakkam, not to its autochthonic species, but to those species which it 
has in common with the rivers of East Sumatra. These facts tend to make probable a former connection between the river system of the Kapuas and the rivers of East Sumatra, which according to the hypothesis explained above must have existed in Pleistocene time before the gradual submerging of the Sunda land.

Finally, a direct proof of the said immersion is given by the magnificent barrier reef which marks the position of the east coast of the submerged Sunda land. This reef, which appropriately may be named the Great Sunda barrier reef (Fig. 3), extends roughly parallel to the south-eastern coast of Borneo, from the Ambungi coral island 120 kilometres south of the mouth of the Kutei or Mahakkam river to a point in $5^{\circ} 40^{\prime}$ South lat. over a length of about 500 kilometres. From Ambungi island it first runs in a south-easterly direction to a point just opposite cape Ongkona on the island of Celebes. From here it turns sharp into a south-westerly and further into a south-south-westerly direction. At the bend opposite cape Ongkona it is 230 kilometres distant from the nearest point of the coast of Borneo, and only 44 kilometres from the coast of Celebes. In a westward direction towards Borneo the depth of the lagoon is very uniform, in the average about 45 metres and nowhere more than 75 metres; eastward of the reef towards the island of Celebes the depth of the sea increases abruptly to 200 , from there rapidly to 1000 , and thence in a small distance to 2385 metres. The barrier reef is interrupted at many places, and its separate coral islands only here and there reach the surface of the sea. A well-marked row of coral islands, the so-called Laurel reefs, constitutes the southern portion of this long barrier reef.

As stated above, the barrier reef ends at about $5^{\circ} 40^{\prime} \mathrm{S}$.; then follows a gap of roo kilometres in width facing a deep embayment of the former Sunda land, into which most probably one of the main watercourses draining that country discharged and deposited a portion of its sediments. More to the south the barrier reef reappears in the Kwong-Eng reef, and can be followed from there as far as the Kangeang islands.

This great barrier reef evidently originated from a fringing reef which in late Pleistocene time extended along the east coast of Sunda land. With the gradual rise of the sea-level after the close of the glacial period and the gradual immersion of the Sunda land the reef has grown up and in many places succeeded in maintaining its position at or near the sealevel. This barrier reef until lately (J. F. Niermeyer, Bibl. 18, p. 884 and Map. xiii. 2) bas not been recognized as such, mainly on account of insufficient knowledge of the depths of the sea in the strait of Makassar, and also on account of its exceptionally great distance from the coast to which it belongs. The large atolls in the southernmost portion of the strait of Makassar are probably originated by the submersion of islands belonging to the Sunda land (Bibl. I4, p. 42x).

On the northern coast of the former Sunda land no barrier reef in the present South China Sea is found indicating the position of the 


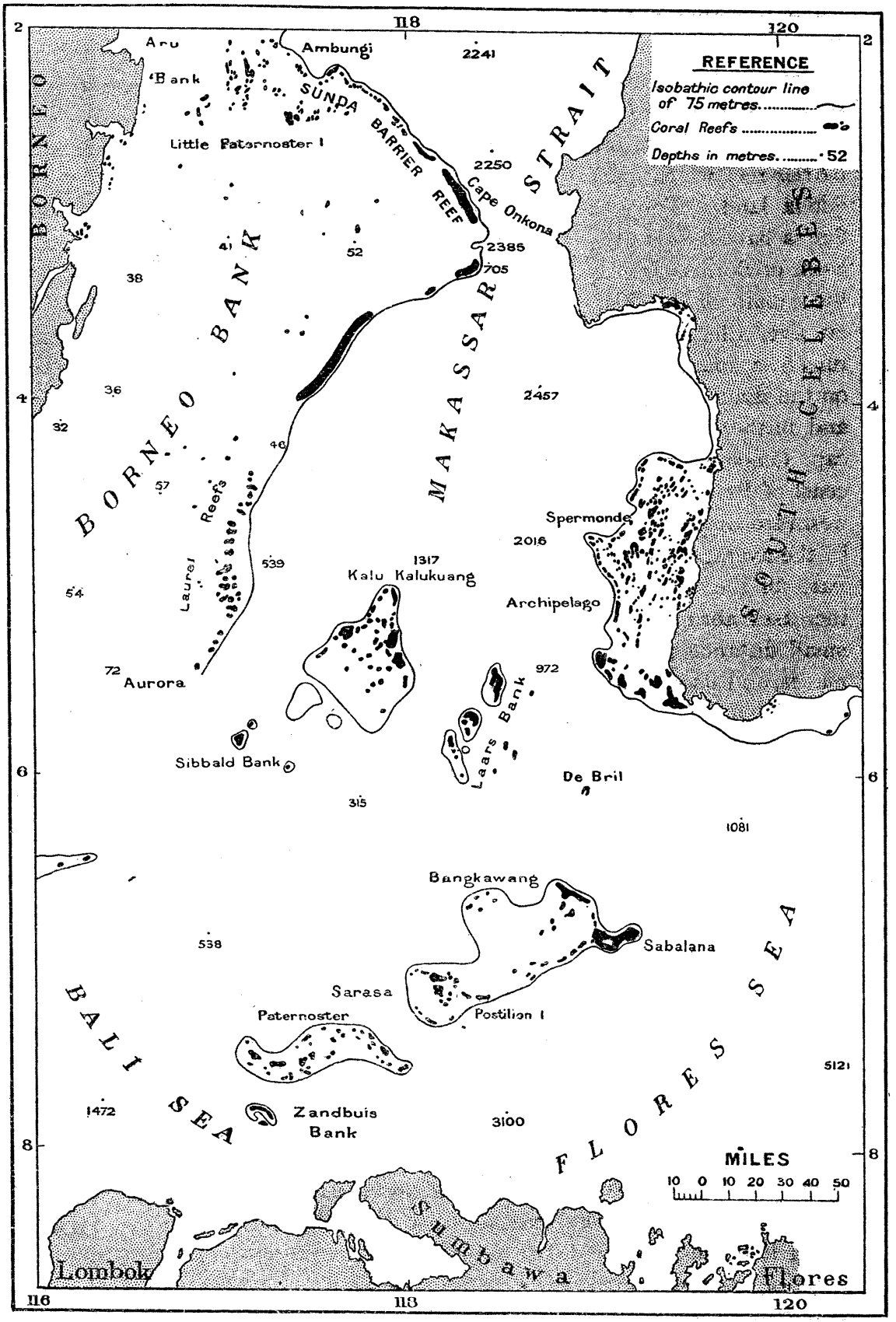

FIG. 3.-THE GREAT SUNDA BARRIER REEF AND ATOLLS 
Pleistocene coast-line. A plausible explanation of this fact is that in Pleistocene time, as is revealed by the present isobathic curves, the land on this coast was very flat and merged gradually into an extensive shelf, which, consisting of loose sand and muddy sediments, probably did not offer favourable conditions for the development of fringing reefs.

The Sahul Shelf.-The Sahul shelf has much the same geological history as the Sunda shelf. In late Pleistocene time the mainland of Australia was connected with New Guinea and the Aru islands by a flat land, probably a peneplain. After the close of the glacial period this low-lying country was flooded by the general rise of the sea-level, and has been converted into the present Sahul shelf.

I have not been able to collect sufficient data to unravel the geological history of this shelf in detail. I shall confine myself, therefore, to this remark, that at many places the position of the Pleistocene coast-line appears to be indicated by coral islands, and that the present shore-line of north-west Australia, as well as that of the south coast of the western portion of New Guinea, is deeply indented. The fiord-like lower course of the Prince Regent River (J. W. Gregory, Bibl. 9, p. 348) presents a typical example of a submerged or drowned valley.

The Deep-Sea Basins and their Surroundings.-The geological history of that portion of the East Indian archipelago to which the remarkable deep-sea basins are confined is quite different from that of the stable portion which has just been dealt with. Although the topography both of the land and the sea-bottom is very complicated, a few main features stand out well, and cannot fail to attract attention. These features are the well-marked trough-shape of the majority of the deep-sea basins, the elongated form of nearly all the islands bordering on these basins, their elongation being in the same direction as that of the troughs; the arrangement of both the basins and the islands in curved rows; and the conspicuous signs of elevation in modern times exhibited by those islands.

It is reasonable to surmise that a genetic connection must exist between the subsidence of the trough-shaped deep-sea basins and the elevation of the adjoining elongated islands ; indeed, the common origin of these antagonistic movements, according to my opinion, has to be sought in one and the same crustal movement, viz. in a process of folding at a certain depth. If the question were raised as to what might be seen at the Earth's surface if an area were folded by crustal movement at a certain depth, I should be inclined to reply that its appearance would be similar to what obtains at present in the eastern portion of the Indian archipelago (Bibl. II, p. 23I).

Near the surface alternating zones of subsidence and of elevation are found, and the ranges of trough-shaped deep-sea basins mark the position of the synclinal axes, whereas the ranges of elevated islands mark the position of the anticlinal axes of the major folds, which are in process of formation at a certain depth. Deep-sea research has proved that these islands, for 
example, those of the non-volcanic range encircling the central Banda sea, stand on a well-marked continuous submarine ridge with a fairly uniform depth of 800-1500 metres, and that they are generally separated from each other by deep channels often of considerable width. These facts ask for explanation.

As soon as the upper portions of the folds which develop at a certain depth approach the Earth's surface and the majority of the rocks under diminished pressure can no more be folded without being fractured (van Hise's zone of fracture), the continuity of the strata will be broken and the culminating portions of the elevating anticlinal axes will be fractured and show at the surface as isolated portions or blocks, their extent and shape being greatly dependent on the geological structure and the differences in rigidity of the composing rocks. This may suffice to explain why an elevating submarine ridge formed by an anticlinal axis will appear at the surface as a row of blocks, i.e. islands separated by deep channels.

But this alone would not yet explain the great width of many of the straits between the islands. Here another factor still may play a rôle (H. A. Brouwer, Bibl. 5). It is an established fact that arcuate anticlinal ridges during their devolopment generally shift their axes in an outward direction, and thus progressively cover more and more ground. The tension resulting from this movement will not interfere with the continuity of the ridge at a certain depth where plastic deformation of the rocks can take place, but near the surface will break up the upper portion of the anticlinal ridge into blocks of different sizes which will be separated by gaps. These blocks may moreover shift their position with regard to each other over more or less considerable distances. Thus a somewhat irregular curved row of islands, resembling the ranges encircling the central portion of the Banda sea, may be formed, the islands being separated one from the other by gaps of varying and often great depths.

In the great geosynclinal area between the continents of Asia and Australia one arc of folding belonging to the Alpine system, and known as the Malay arc, appears to originate from the Burma arc, the southeasternmost range of the Eastern Himalayan system, and can be followed through the domain of the East Indian archipelago from the extreme north-western end of Sumatra, through this island and the island of Java, and from there in a double row of islands as far as the Banda sea.

In its western section where it borders on the Indian Ocean, as in the central portion of the island of Sumatra, this arc now consists of two major folds, as is illustrated by an ideal cross-section (Fig. 4)* from the Indian Ocean towards the stable portion of the Sunda land. It would show the following sequence :

* Verbeek has first recognized that these major folds, which date from pre-Tertiary time in their successive phases of development, always have determined the principal features of the geological structure of Sumatra. Bibl. 23, pp. 543-550, and figs. 50-55. 
r. Indian Ocean.

2. Sunda trough, first geosyncline.

3. Range of coastal islands girdling the west coast of Sumatra including the Mentawei islands, first geoanticline.

4. Mentawei trough and corresponding trough-shaped depths, second geosyncline.

5. Non-volcanic and volcanic mountain ranges of Sumatra and Java, second geoanticline.

6. Tertiary terrain, folded in late Tertiary and early Pleistocene time, now practically stable, third geosyncline.

7. Stable Sunda land, including the Sunda shelf.

In this western portion the position of the following deep-sea basins is determined by the present phase of the process of folding :

I. The Andaman basin.

2. The Mentawei trough.

3. The Sunda trough.

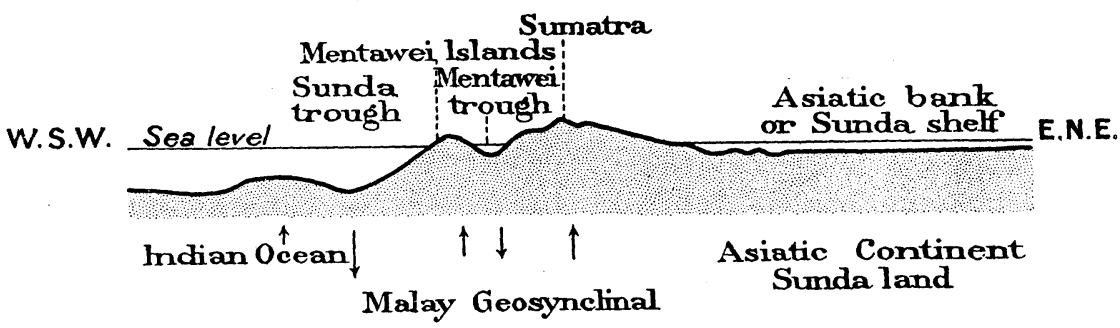

Fig. 4.-Schematic representation of late Tertiary Pleistocene and post-Pleistocene crustal movements in the western section of the Malay or Australasian geosynclinal area

In the south-eastern section of the same arc the process of folding has been modified by the proximity of the stable Australian continent and the thrusting against its edge.

In its easternmost section in the Moluccas the crustal warping is of an extremely complicated nature on account of the fact that two great orogenetic systems, the Alpine system and the circum-Pacific system," here meet and are interlaced. The Malay arc belonging to the Alpine folding system in the Moluccas is represented by two more or less parallel curved rows of islands, the inner being volcanic, the outer nonvolcanic. After having curved round the Banda sea, it is completely rolled on itself and disappears in the Banda basin (H. A. Brouwer, Bibl. 3). The last island of the non-volcanic row appears to be the island of Buru, and the volcanic row appears to end in the Banda group or possibly beyond the shoals of the Lucipara group in the Gunung Api. $\dagger$

* This is the current opinion endorsed by E. Haug and P. Sarasin. It remains, however, open to discussion whether it would not be more recommendable to distinguish between a circum-Asiatic system and an Australo-Pacific system.

$\dagger$ There is some reason to surmise that the Ceram-Buru arc being broken off west of Buru might have its continuation through the Tukang Besi islands, and from these through Buton and the portion of Celebes east of the Boni-Posso depression. 
The major folds of the Malay arc in its eastern section determine the position of the following sea basins and ranges of elevated islands.

I. Australian continent and Sahul shelf.

II. Folds of the Malay arc.

I. Timor trough, Kei trough, Ceram-Aru trough, Ceram sea, first geosyncline.

2. Row of fifteen larger and numerous smaller non-volcanic islands ranging from Sumba over Timor to Buru, first geoanticline. This curved row, after its most important constituents, is also known as the Timor-Ceram row, or the Timor-Ceram arc.

3. Savu sea, Wetter trough, East Banda trough including the Weber deep, second geosyncline.

4. Row of eight larger and numerous smaller volcanic islands and rocks, ranging from Bali over Alor and Wetter to the Banda group, possibly to the Lucipara shoals and Gunung Api, second geoanticline.

5. Flores sea and the central Banda sea, third geosyncline.

These relations are illustrated in an ideal section (Fig. 5). More to

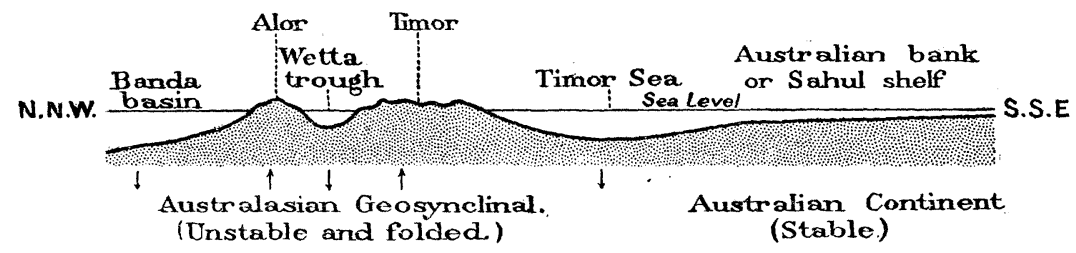

Fig. 5. - Schematic representation of Pleistocene and post-Pleistocene crustal movement in the eastern section of the Australasian or Malay geosynclinal

the north the position of the majority of the deep-sea basins of the East Indian archipelago has been determined by the major folds in the geosynclinal area bordering on the east coast of Asia and belonging to the circum-Pacific system. It appears that the remarkable basins of the Sulu sea and the Celebes sea, including the Strait of Makassar, are modified troughs lying between anticlinal axes fanning out from the Philippine islands towards the south (W. D. Smith, Bibl. 2I).

The tectonics of North Borneo, the Philippines, and New Guinea are however, as yet little known, and it would be hazardous to enunciate speculative ideas on the relations between the deep-sea basins of the northern and north-eastern portion of the East Indian archipelago and the marginal folding in the Pacific Ocean along the coast of the Australian continent and of New Guinea.

Distribution of Coral Reefs. - The distribution of coral reefs and coral islands in the unstable or geosynclinal portion of the East Indian archipelago is well in harmony with the theory the brief outlines of which are given above, according to which both the deep-sea troughs and the ranges of islands separating them are in their present shape the result of one and 
the same process of folding in the earth's crust in Pleistocene and postPleistocene time, which most probably still continues.

The first conspicuous fact is, that the islands in this region of complicated topography which in general mark the position of the main anticlinal axes almost without exception are fringed by reefs and possess a terraced appearance caused by extinct coral reefs being elevated to various heights. To quote an instance, in the interior of the island of Timor coral reefs of Pleistocene age are found elevated to a height of nearly I 300 metres above sea-level. Kisser with its terraces is one of the finest specimens of a terraced island. On several other islands the number of the elevated terraces is higher still, viz. thirteen on Kambing, fifteen on Dai, and sixteen on Dawara, according to Verbeek. The process of elevation is most probably still going on. This is exactly what the theory requires. Another not less conspicuous fact, that the trough-shaped deep-sea basins separating the ranges of elevated islands one from the other are, taken as a whole, free of barrier reefs and atolls, asks for a special explanation.

Undoubtedly the fact that these basins, marking the position of the synclinal axes, and thus indicating areas of subsidence, do not possess reef types which are characteristic of such areas appears to be in contradiction with the theory advocated above. If, however, one bears in mind that more than anything else the latest crustal warping has resulted in the emerging of ranges of islands from the sea in the anticlinal areas and in the deepening of pre-existing shallow seas in the synclinal areas, a plausible explanation can be given.

Before the latest still continuing phase of the orogenetic movements set in, the general topography of the eastern portion of the archipelago as a result of an anterior folding of probably late Miocene age resembled the present one, with this material difference, that the sea-basins were much shallower than they are to-day, and that the islands were lower and smaller. In fact many of the latter were entirely submerged and did not yet exist as such. The Pleistocene and post-Pleistocene folds described here are probably engrafted upon the older Tertiary folds.

During the process of emersion the islands continually grew larger and finally attained their present size. Fringing reefs were continually formed along the coasts during this period of upheaval, and began to be elevated as soon as they had been formed. Where they have not been destroyed later by erosion they now form part of the elevated terraces. The islands this growing at the cost of the sea-basins, there was practically no chance for any of the fringing reefs to become converted into a barrier reef.

In this line of reasoning one has, of course, to take for granted that the pre-existing former shallower seas were free from islands and shoals. A strict proof of the accuracy of this postulate cannot be given as yet.

Fig. 6 is meant to illustrate schematically a possible mode of origin of the islands of the Moluccas with their elevated reefs, and of the deep-sea basins separating them which are devoid of barrier reefs and atolls. 
Another alternative appears to be admissible. The pre-existing shallower seas may have possessed fringed islands or coral shoals, but these may have been drowned now. The downward movement caused by diastrophism in this case must have been so rapid that it could no more be compensated by the upward growth of the reef-building corals. A remarkable dredging carried out by the Siboga on I September 1900 in the deeper portion of the Ceram sea appears to give an instance. From a depth ranging from 1633 to 1304 metres over a distance of no less than 3 nautical miles large quantities of recent reef-building coral were then dredged, which had died off, and by a thick cover of manganese revealed their long stay in the sea-water after their dying off. The nearest point in these regions where living reef-building corals occur near the surface lies at 42 kilometres from the point where the dredging took place, so that those corals in the deep sea could not originate there. In order to explain the result of this dredging, I should rather suppose that on that spot in the

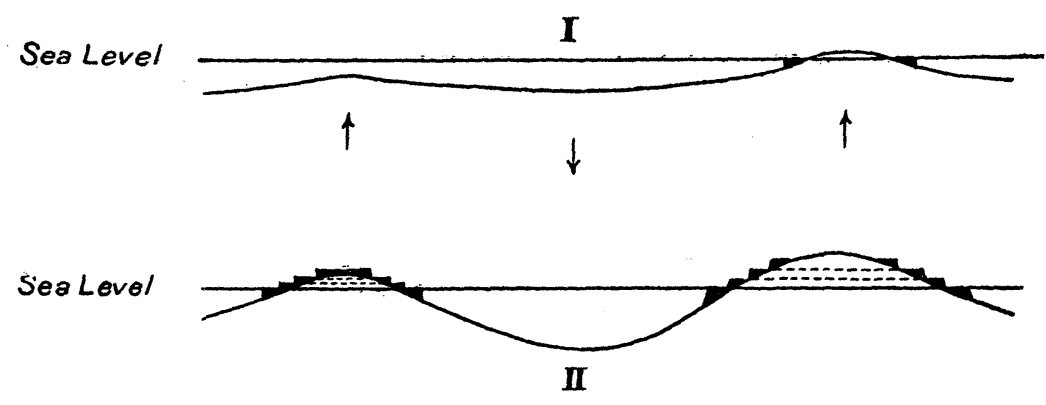

Fig. 6.-Ideal cross-sections illustrating the mode of origin of the deep-sea basins and the elevated terraced islands of the Moluccas by recent deep-seated folding. I. Before the folding. II. After the folding. Coral reefs : Black

Ceram sea from the sea-bottom, which lies at a depth of about 1600 metres, a drowned coral island rises to about $\mathrm{r} 300$ metres below sea-level.

Accepting this alternative, one is led to surmise that one of the reasons why the present deep-sea basins of the East Indian archipelago, although formed by subsidence, are free from reef structures of the types of barrier reefs and atolls, is that these reefs have been drowned. Detailed deep-sea research may throw in future more light on this subject.

Some exceptions, however, are known to exist within the area concerned. A few barrier reefs and atolls are found in the basins of the unstable portion of the East Indian archipelago, as well as along the south-western coast of Sumatra, as in the archipelago of the Moluccas. I will quote a few instances from the latter region only. The group of islands southeast of Celebes, known as the Tukang Besi islands (Fig. 7), consists of four rows of islands, trending about from north-west to south-east. Two of these ranges consist of upheaved islands terraced by elevated reefs and girdled by well-developed fringing reefs; the two remaining ranges which alternate with the former consist of small rock groups without traces of 
elevated reefs encircled by barrier reefs, and of atolls or atolliform coral islands (Bibl. ro).

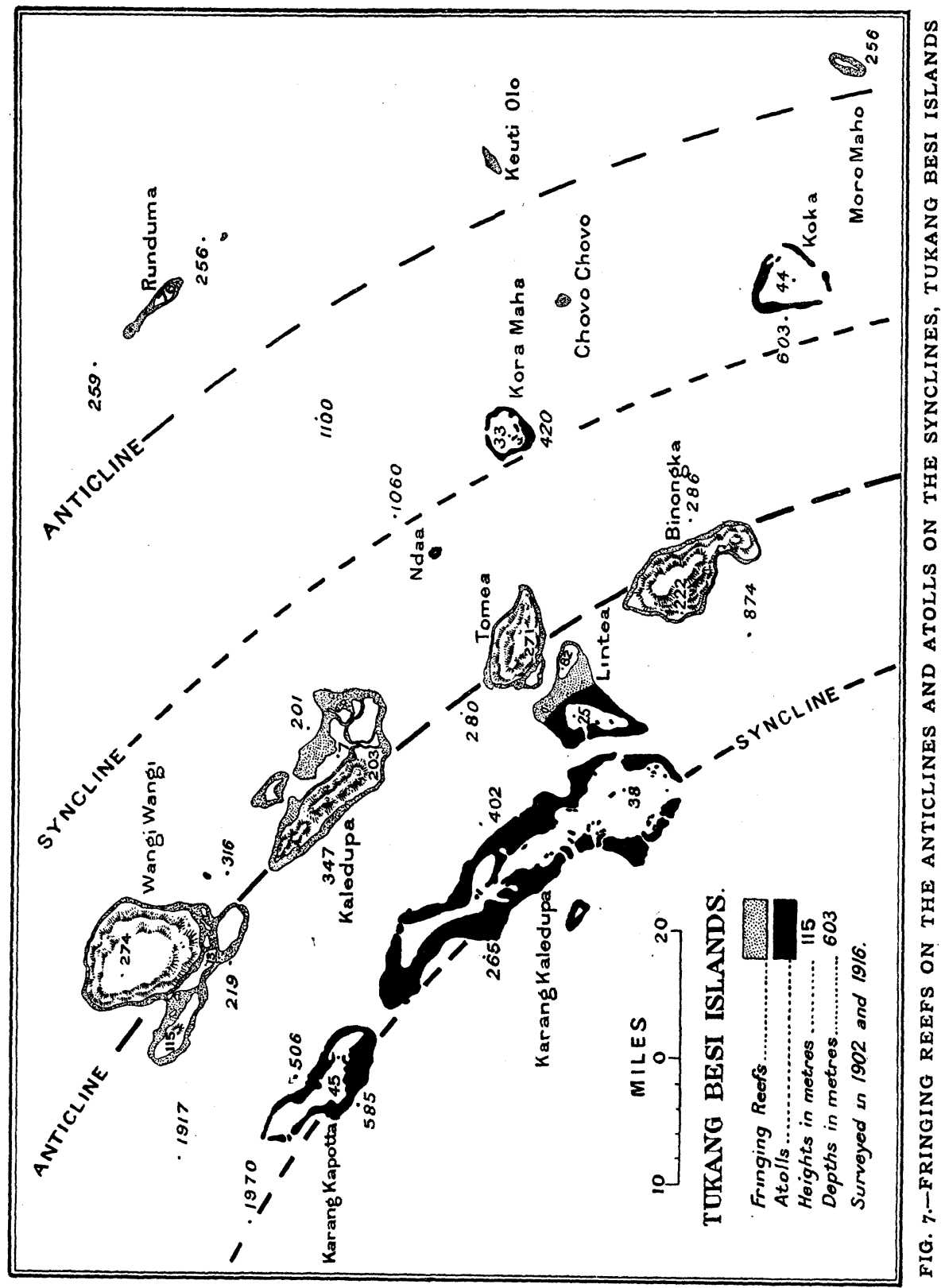

Evidently in this case the terraced islands mark the anticlinal axes and the reef-encircled islands and atolls the synclinal axes of an area of active 
folding at a certain depth. Some other instances are equally interesting, because they show how the development of the reefs on and along the anticlinal axes partakes of all the modifications in shape these axes undergo during their mode of formation. Consequently as a rule the upward movement of the island will not be uniform, neither will one island be elevated exactly as much as another, nor will the elevation be the same all over one and the same island. On the contrary, one must expect to find differential movements, just as well on comparing one island with another as on comparing different portions of one and the same island with each other.

First of all, the anticlinal axis may in its line of trend develop culminations and depressions (cp. H. A. Brouwer, Bibl. 4, p. 820), and thus show a more or less important pitch. Barrier-reefs and atolls may develop where
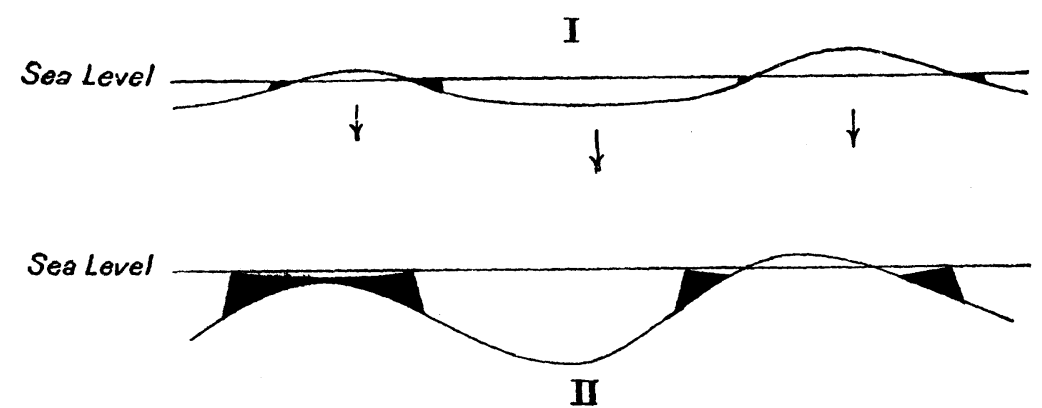

Fig. 8.-Ideal cross-sections illustrating the mode of origin of barrier reefs and atolls in anticlinal areas by folding and pitching of the anticlinal axis. I. Before the folding. II. After the folding. Coral reefs: Black

such depressions occur (Fig. 8). The axis of the Timor-Ceram (SumbaBuru) anticline shows a well-marked depression in the group of the Sermata islands. In this group, encircling Luang and the Ukenas islands, beautiful barrier reefs are found. The pitch of the axis of the TimorCeram (Sumba-Buru) anticline, both from the west and from the east towards the island of Luang, can be calculated from the position of the uppermost elevated modern reefs in the adjoining islands of the range. Going from west to east these elevated reefs are found at the following altitudes :

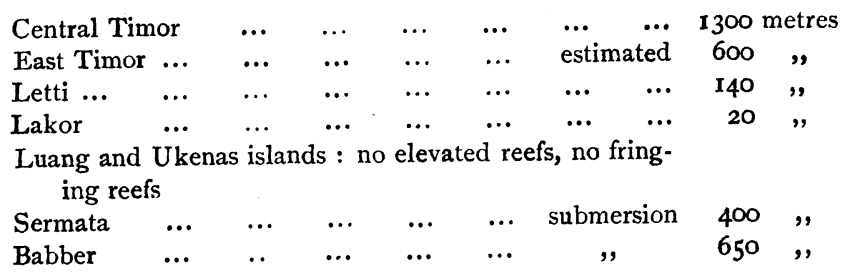

Sometimes a submarine anticlinal axis pitching downwards can be followed by the position of coral islands which have grown up from its 
submerged portion. Thus probably the Lucipara coral shoal marks the continuation of the submerged volcanic range of islands, Wetter-Banda, in the central Banda sea.

Secondly, the bend of the anticlinal axis may be accentuated during the process of upheaval, which in a normal case of folding will often occur. The uprise in such a case is no more uniform, and the elevated reefs are no longer found in a horizontal position, but more or less sloping. The island of Timor furnishes a good example, as I have shown (Bibl. II, p. 228 , and 12, pp. 693-696). The coral reefs are differentially elevated on this island; reefs of one and the same age, which in places are still coherent along the central axis of the island, are much more elevated than those nearer to the north and south coasts.

In fact, the reefs of the Dirun ridge south of the Lakaän near the central axis of the island occur now at an altitude of 1283 metres, about 680 metres higher than those on the hills of the north coast at Balbo. The big reef also of the Gempol cliff in the central portion of the island not far from Kapan has an altitude of $125^{\circ}$ metres above sea-level, whereas in the southern mountain ranges near Niki-Niki the highest altitude at which coral reefs are found is only. $75^{\circ}$ metres. The elevation of the central portion of the island has been from the beginning somewhat stronger than that of the southern and northern coastal regions, the entire island thus forming the feebly curved arc of a large anticline.

Furthermore, the axis of the developing anticline can shift its position (H. A. Brouwer, Bibl. 4, p. 822), which will cause tilting and unsymmetrical

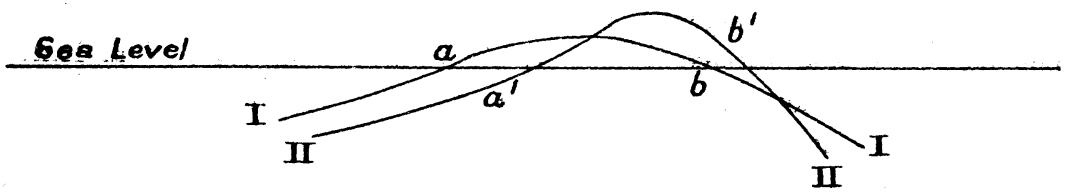

Fig. 9-Successive stages of development of an island situated on an anticlinal axis. Fringing reef formed at $a$ and $b$ during Stage 1 . would be found at $a^{\prime}$ and $b^{\prime}$ in a later Stage II. The fringing reef at $a$ (Stage I.) would have been submerged and a barrier-reef have developed at $a^{\prime}$ (Stage II.), whereas the fringing reef at $b$ (Stage I.) would have been elevated and been found at $b^{\prime}$ (Stage II.).

development of the elevated reefs. Such a shift of the axis can coincide with alterations in the dip of the sides of the anticline (Fig. 9), and the result can be the development of a barrier reef at one coast of an island, whereas at the opposite coast simultaneously fringing reefs are elevated above sealevel. Thus in this case simultaneously on the coasts of one and the same island fringing and elevated reefs as well as barrier reefs can be developed. On the islands of Roti and Sumba the reef terraces are distinctly tilted and unsymmetrical. The island of Jamdena offers a good example of subsidence at one coast, the northern coast, and upheaval at the opposite coast.

Finally, it may be pointed out that on studying the occurrence and the distribution of coral reefs in the unstable or orogenetically active portion 
of the East Indian archipelago, one must not lose sight of the fact that the oscillations of the sea-level in connection with the Ice Age have taken place here just as well as in the stable Sunda land. These oscillations may probably give an explanation of the origin of some of the barrier reefs which occur along the coasts of some of the islands adjoining deep-sea basins, as has been shown by Niermeyer (Bibl. I8). Only the effect of these oscillations has been modified or totally overwhelmed here by that of the orogenetic forces, whereas in the stable Sunda land it is shown as such and unmodified.

To sum up, the latest researches on the geological history of the deepsea basins of the East Indian archipelago and of the islands connected with them, have led to the following conclusions and suppositions :

I. The Australasian Mediterranean Sea consists of two strongly contrasting areas, one with an exceptionally uniform and undisturbed submarine topography, and another with an extremely complicated structure.

2. The first area is that of the great shelves, which are attached to the continents of Asia and Australia; the other that of the enclosed deep-sea basins.

3. The area of the shelf seas has been stable and has not been affected by diastrophism, at least since the end of the Pliocene Age. The area to which the deep-sea basins belong has since that time continued to be unstable as it was before, and has been, and is still, the seat of powerful orogenetic movements.

4. The shelf seas owe their origin to the submersion of a strongly peneplainized land surface caused by a rise of the sea-level of at least 40 fathoms, consequent on the melting of the ice-caps at and after the close of the Pleistocene Ice Age.

5. The deep-sea basins and the adjoining elevated islands are simultaneously formed, and continue to be developed by a process of folding at a certain depth.

6. The islands are elevated and grouped in rows because they are nothing but the culminating and fractured portions of submarine ridges which rise up on top of the anticlinal portions of the deep-seated folds. The trend of each row of islands roughly indicates the line of strike of the anticlinal axis of each of these folds.

7. The deep-sea basins are elongated more or less exactly parallel to the adjoining rows of islands, because they are formed above the subsiding synclinal portions of the deep-seated folds.

8. All the islands are, as a rule, upheaved, but the upheaval has been very unequal, as can be observed if the islands are compared one with another, or if a comparative examination be made of different portions of one island. In exceptional cases the upheaval is wanting, and even subsidence may occur instead, as has been explained above.

9. The consecutive phases of development of the anticlinal portions of 
the folds are revealed at the surface by the mode of development of the reefs, and can be studied by comparing the character and the relative position of extinct reefs of the same age,

\section{BIBLIOGRAPHY}

I. A. AgAssiz, 'Three Cruises of the steamer Blake.' London, i888. 2 vols.

2. O. B. BöGGILD, 'Meeresgrundproben der Siboga-Expedition,' Siboga expeditie, Monograph LXV. Leiden, IgI6.

3. H. A. BROUWER, "Geol. overzicht van het oostelijk gedeelte van den O. I. Archipel.," Faarboek van het Mijnwezen, Jaarg. 46, Verh. 2, p. I. I9I9.

4. H. A. Brouwer, "On Reefcaps," Proc. Royal Acad., Amsterdam, Nov. 19r8, 21, p. 816. I919.

5. H. A. Brouwer, "Vergelijkende tektoniek," Handel. van het XVII ${ }^{\mathrm{e}}$ Ned. Natuur- en Geneesk. Congres I9I9. Haarlem, I920.

$\rightarrow$ R. A. Daly, "Pleistocene Glaciation and the Coral Reef Problem," Amer. Fourn. of Science, 30, p. 297. 1910.

7. R. A. DALY, "The Glacial Control Theory of Coral Reefs," Proc. of the Amer. Acad. of Arts and Sciences, vol. 51, p. 157. 1915.

$\rightarrow$ W. EARLE, "On the Physical Structure and Arrangement of the Islands of the Indian Archipelago," Fourn. Royal Geogr. Soc., 15, p. 358. 1845.

9. J. W. GREGORY, 'The Nature and Origin of Fiords.' London, I9I3.

Io. 'Map of the Toekang Besi Islands, surveyed in the years 1902 and I9I6.' No. 317. Hydrographie Min. van Marine. 's-Gravenhage, I9I9.

II. G. A. F. MOlengraAfF, " On Recent Crustal Movements in the Island of Timor, and their bearing on the Geological History of the East Indian Archipelago," Proc. Royal Acad., Amsterdam, Juni 19i2, vol. I5, p. 224. IgI2.

12. G. A. F. MolengraAfF, "Folded Mountain Chains, Overthrust Sheets and Block-faulted Mountains in the East Indian Archipelago," Compte Rendu du XII Congrès géol. internat., Toronto, 1913, p. 689. Ottawa, I9I5.

13. G. A. F. Molengraaff, "The Coral Reef Problem and Isostasy," Proc. Royal Acad., Amsterdam, Juni i916, vol. I9, p. 610. I9ı6.

14. G. A. F. MolengraAfF and Max Weber, "Het verband tusschen den plistoceenen ijstijd en het ontstaan der Soenda Zee en de invloed daarvan op de verspreiding der koraalriffen en op de land- en zoetwaterfauna," Versl. Kon. Akad.van Wetenschappen Amsterdam, Nov. 1919, 27, p. 507, 1920. An English translation of this paper is now printed.

I5. J. Murray and A.' F. Renard, 'Report on Deep-Sea Deposits. Scientific Results of the Voyage of H.M.S. Challenger, 1873-1876.' London, I89I.

16. J. MURRAY and R. Philippi, 'Die Grundproben der Deutschen TiefseeExpedition.' Deutsche Tiefsee-Expedition. Bd. X. Jena, 1908.

17. J. MURRAY and J. HJORT. ' The Depths of the Oceans.' London, I9I2.

I8. J. F. Niermeyer, "Barrière-riffen en atollen in de Oost-Indiese Archipel.," Tijdschrift Kon. Ned. Aardr. Gen. 2, 28, p. 880. I9I I.

19. A. PENCK, "Schwankungen des Meeresspiegels," Fahrb. der geogr. Ges. zu München, 7, p. 47. I882.

20. A. PENCK, 'Morphologie der Erdoberfläche,' 2, p. 66o. Stuttgart, I894.

2I. W. D. Sмiтh, "The Philippine Islands," Handb. der "region. Geologie, vol. 6, 5, p. I. I910. 
22. G. F. Trdeman, 'Hydrographic Results of the Siboga Expedition,' Siboga-expeditie, Monograph III. Map I. and II. Leiden, I903.

23. R. D. M. VERBEEK, 'Topographische en geologische beschrijving van een gedeelte van Sumatra's Westkust.' Batavia, I883.

24. R. D. M. VERBEEK, "Molukken-Verslag," Faarboek wan het Mijnwezen, vol. 37, Wet. Ged. Batavia, Igo8.

25. MAX Weber. See above, No. I 4 .

Before the paper the PRESIDENT said: The lecturer this evening is Dr. Molengraaff, who is the head of the Geological Laboratory at the Technical Institute, Delft. He has paid three long visits to the Dutch East Indies and travelled in the interior of Borneo and Celebes, and is one of the greatest authorities on that region. We and the Dutch, for many centuries, have been rivals in the East Indies, and I understand from Dr. Molengraaff's paper that he proposes that we should be rivals for many million years yet. $\mathrm{He}$ is going to give us an account of how the Himalayas of the future are arising out of the Dutch East Indian archipelago. In that part of the Indies over which we hold administration there are the highest mountains in the world, but Dr. Molengraaff will tell you how perhaps still higher mountains are at this very moment emerging from out the ocean depths which may in course of time-I do not know how long-arise and rival the Himalayas. It is by great kindness on the part of Dr. Molengraaff that he is speaking to us here in England. $\mathrm{He}$ has taken the trouble to come over from Holland to read us this paper. $\mathrm{He}$ has not had much practice lately in giving public lectures in English, but I am sure you will all appreciate his consideration in speaking to us in our own language.

\section{Dr. Molengraaff then read the paper printed above, and a discussion followed.}

Dr. FRIDTJOF NANSEN : I am very unexpectedly called upon to speak tonight, and I can say only it is with the deepest interest I have listened, as I am sure we all have listened, to this most interesting lecture, and heard all these very important results that have been obtained by this hydrographical work in the East Indies. There is one part of this lecture which has appealed specially to me, as it covers much the same ground as I myself have been investigating, namely, the shelves of this Mediterranean sea of the tropics. It is one of the biggest submarine shelves in the world. There is another shelf of similar large extension, but formed in different circumstances, north of Siberia, which I had the very good fortune to investigate myself. The depths are, as far as I understand, very much the same; the configuration seems to be very similar, and the edge lies very nearly in the same depth. These are two of the greatest shelves in the world; the third is east of South America. The depth is to a great extent about 40 fathoms, or less than 100 metres. The shelf north of Siberia is something like 400 or 500 miles broad, and the sculpturing of the surface seems to be very much the same. You call it a peneplain. I think that is quite right, but it is a peneplain that at least in the north has to some great extent also been levelled by marine denudation. I don't know how far that is the case with the shelf in the south, but it is with the shelves of the Polar Sea. There the marine denudation is chiefly caused, in my opinion, by an action not possible in the tropics, namely by the frost. I think the frost on the shoreline is one of the chief reasons why the shelves on all sides of the Polar Sea are very broad-very broad north of Siberia, and I am sure we are not mistaken if we think it also very broad north of the unknown coast of the American continent. 


\section{DEEP SEA BASINS}

\section{Andaman Basin}

II. Mentawei Basin

III. Mentawei or Sunda Trough

IV. Java Trough

V. Timor Sea

VI. Kei Trough

VII. Ceram-Aru Trough

VIII. Flores Sea

IX. Savu Sea

X. Wetta Trough

XI. Saleyer Trough

XII. Buton Trough

XIII. Kalao Trough

XIV. North-Western Banda Sea

XV Central Banda Sea

XVI. Eastern Banda Sea and Weber Deep

XVII. Batyan Trough

XVIII. Gorontalo Trough

XIX. Sangir Trough

XX. Togean Basin

XXI. Tomini Basin

XXII. Celebes Sea, including Strait of Makassar

XXIII. Sulu Basin

XXIV. Palawan Trough

XXV. South China Sea

XXVl. Mindanao Trough

XXVII, Halmaheira Basin

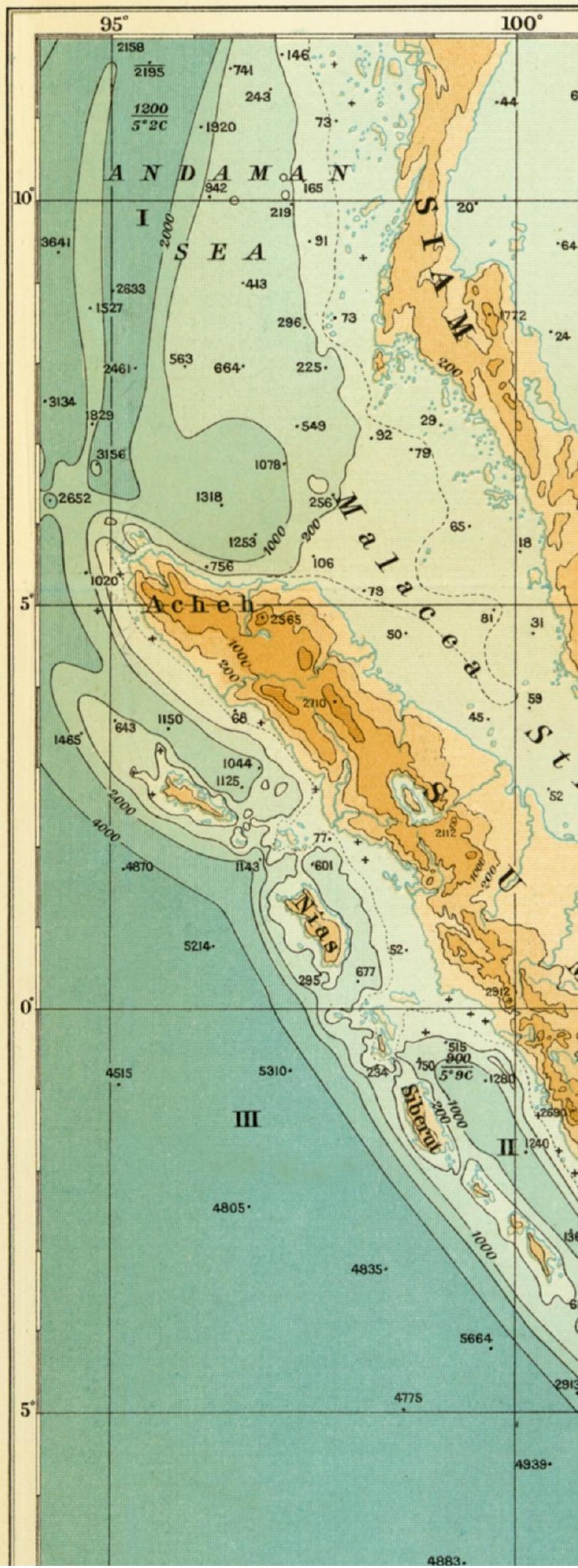

4883. 
THE EA

to illustr

MILES 100

KILOMETRES

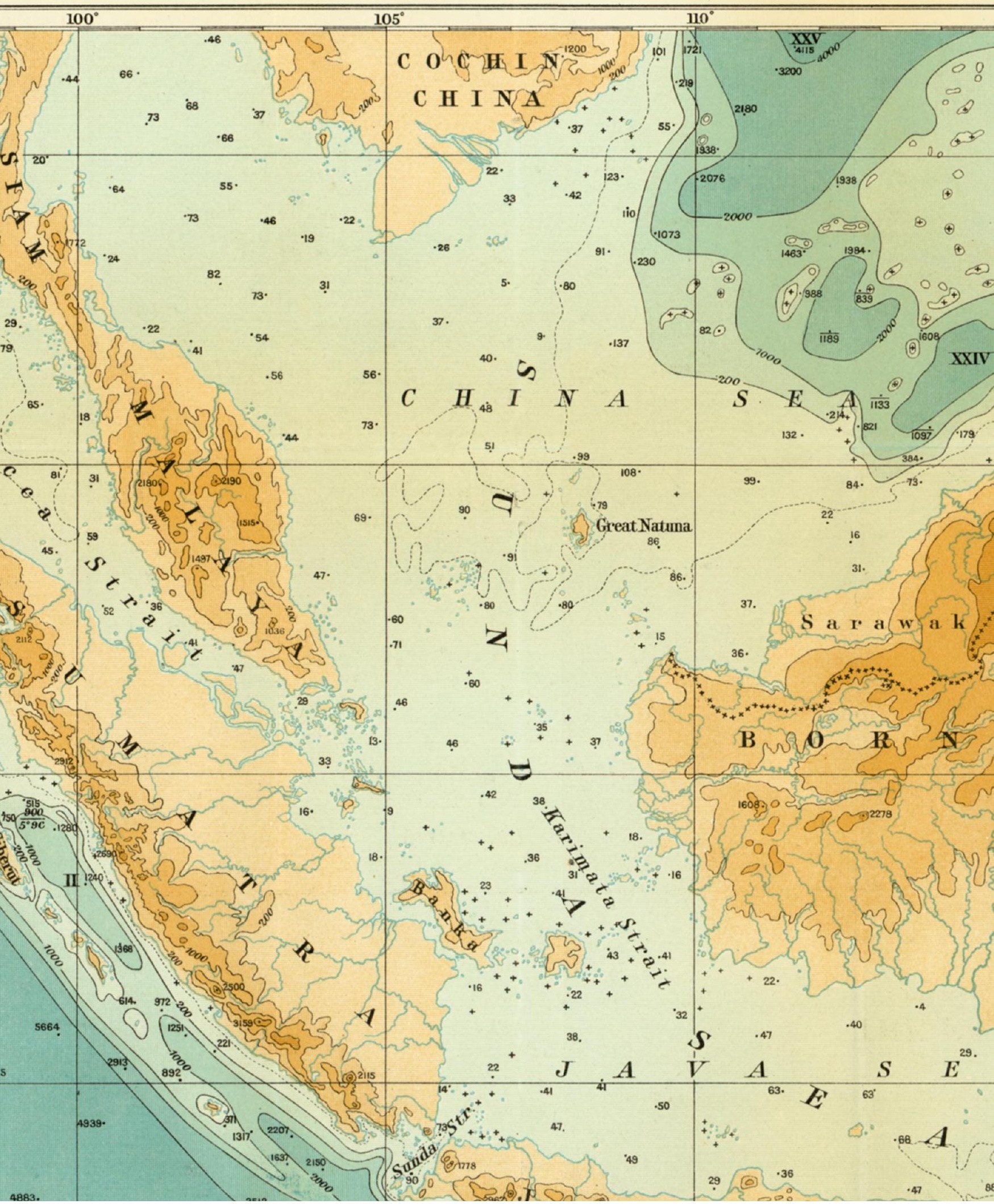




\section{HE EAST INDIAN ARCHIPELAGO}

\section{to illustrate the paper by Prof. G.A.F.Molengraaff.}

Scale, $1 / 10,000,000$ or $1 / 10 \mathrm{M}$.

$\begin{array}{llllll} & 100 \\ \text { ILES }\end{array}$

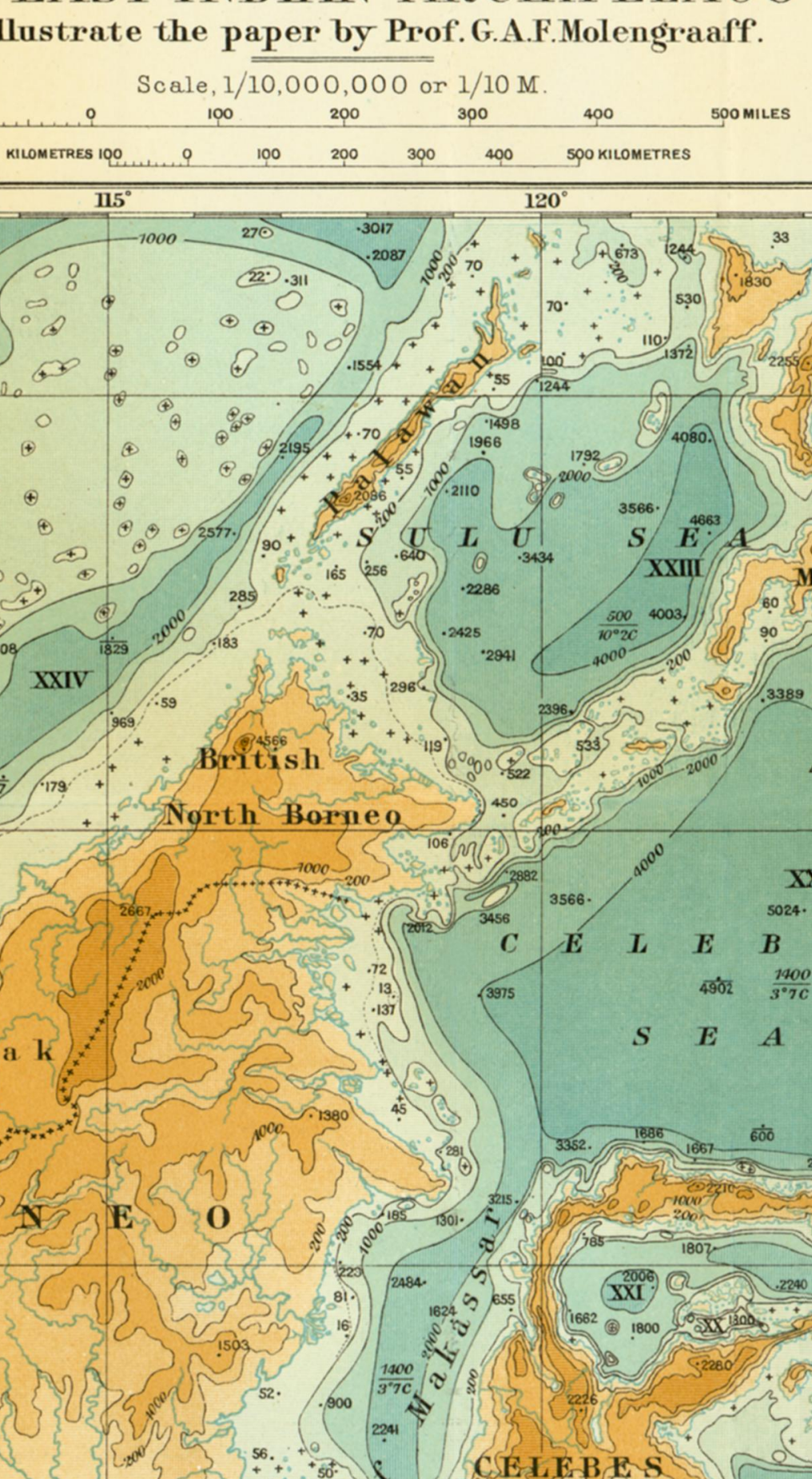

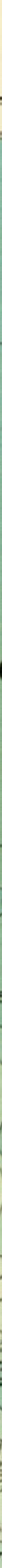

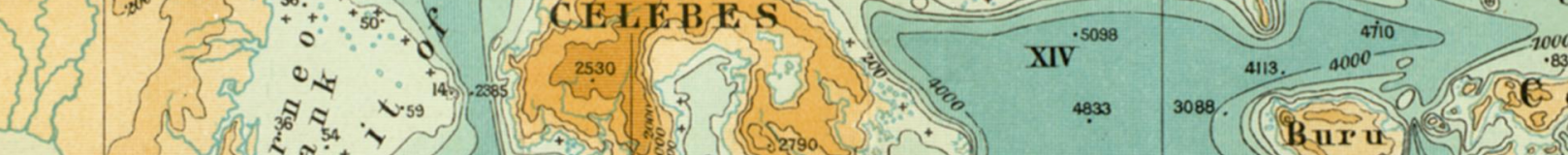

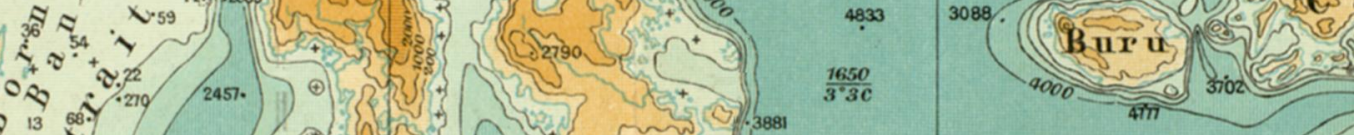

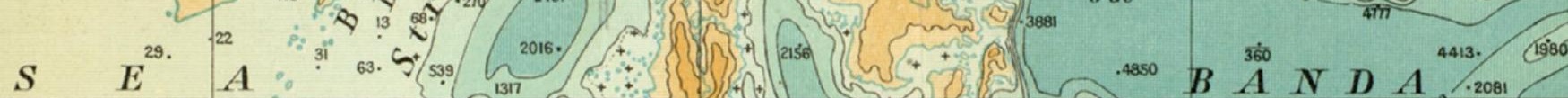

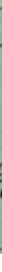


THE GEOGRAPHICAL JOURNAL, FEB. 1921. 140

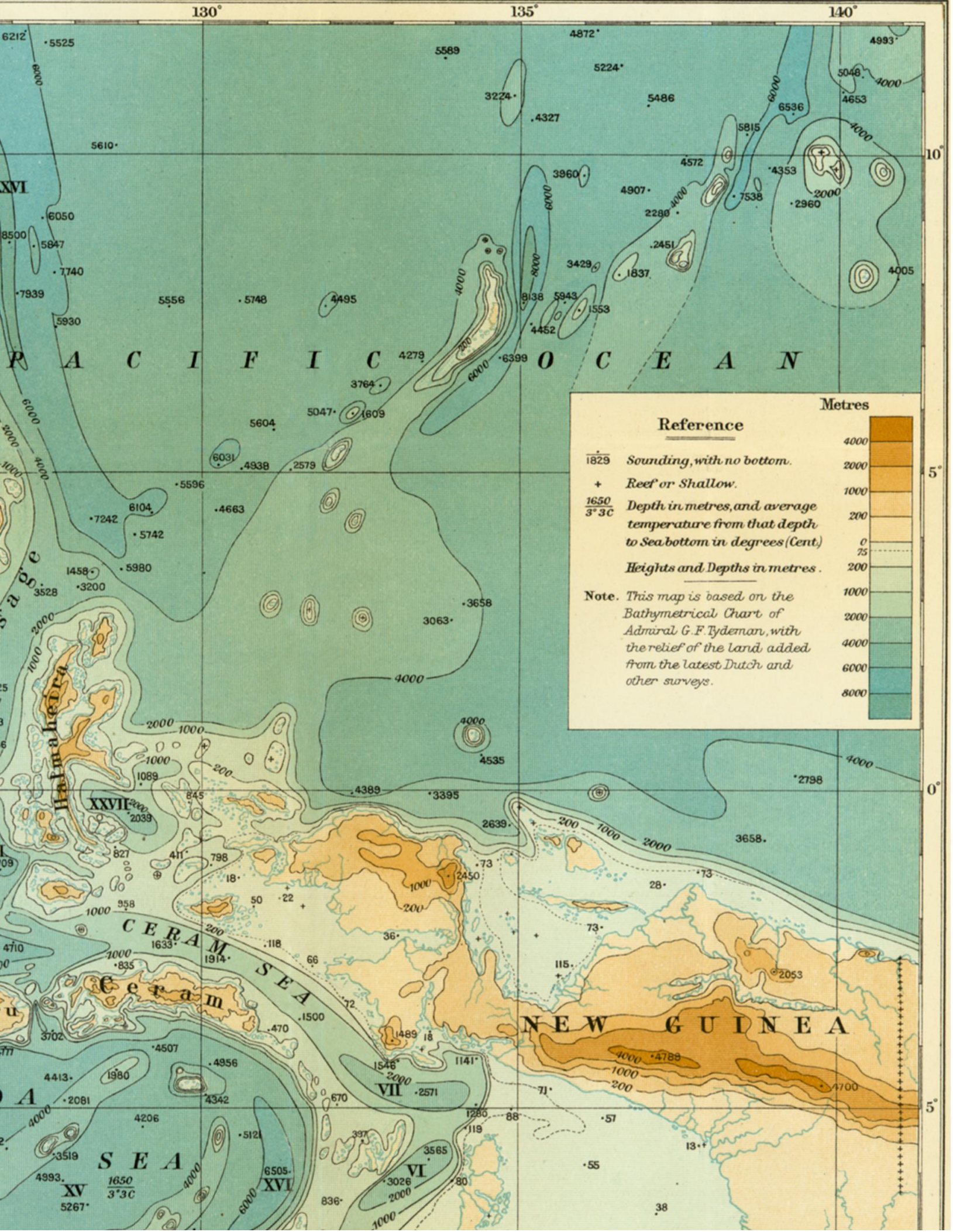

This content downloaded from 193.255.248.150 on Fri, 26 Dec 2014 09:22:42 AM All use subject to JSTOR Terms and Conditions 


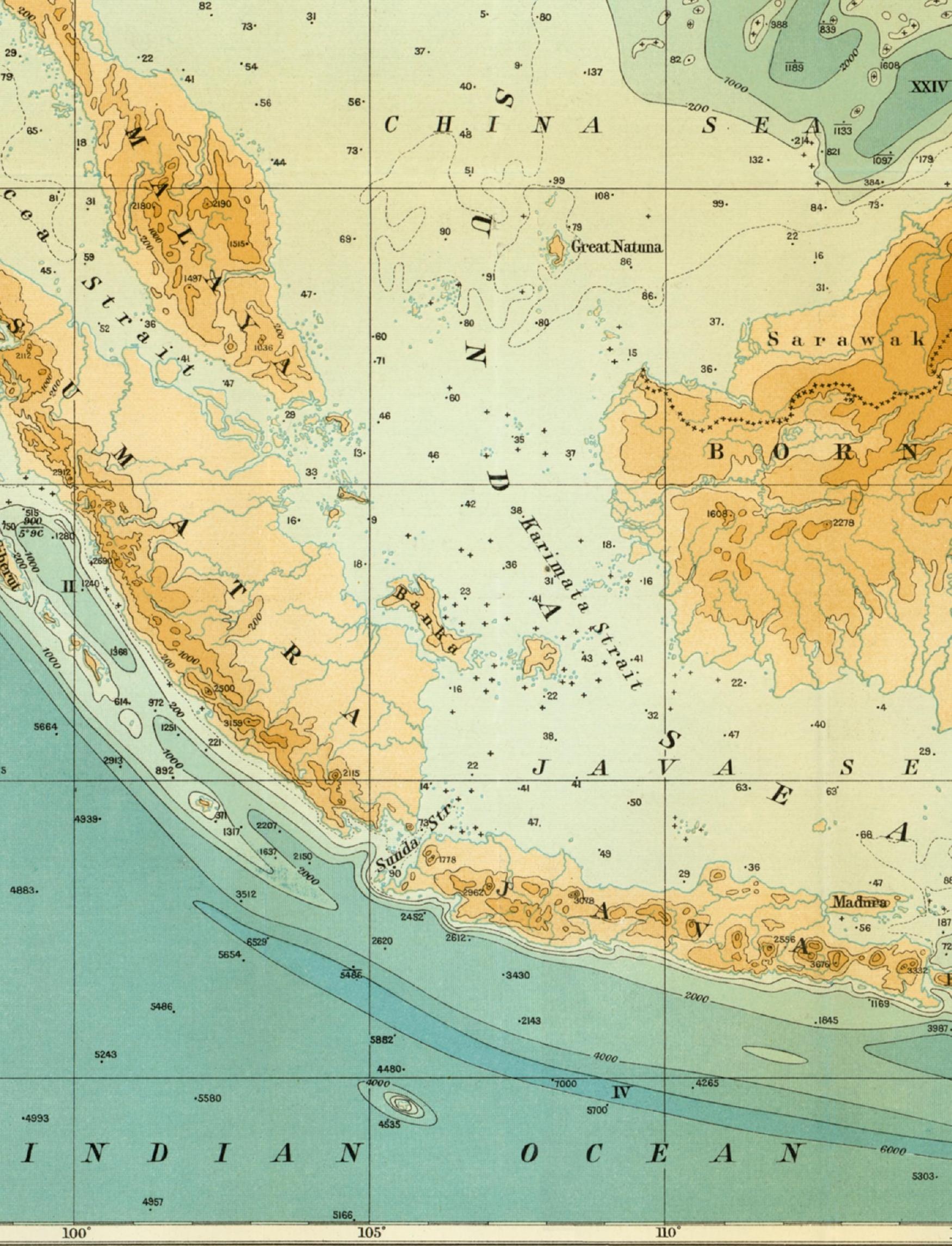



